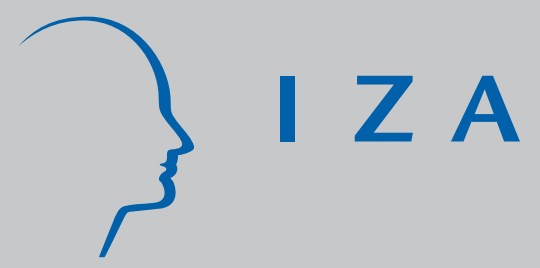

IZA DP No. 59

Canadian Immigration Experience: Any Lessons for Europe?

Don J. DeVoretz

Samuel A. Laryea

September 1999 


\title{
Canadian Immigration Experience: Any Lessons for Europe?
}

\author{
Don J. DeVoretz \\ RIIM, Simon Fraser University, Burnaby, Canada \\ Samuel A. Laryea \\ RIIM, Simon Fraser University, Burnaby, Canada
}

\section{Discussion Paper No. 59 \\ September 1999}

\author{
IZA \\ P.O. Box 7240 \\ D-53072 Bonn \\ Germany \\ Tel.: +49-228-3894-0 \\ Fax: +49-228-3894-210 \\ Email: iza@iza.org
}

This Discussion Paper is issued within the framework of IZA's research areas Mobility and Flexibility of Labor Markets, Internationalization of Labor Markets and The Welfare State and Labor Markets. Any opinions expressed here are those of the author(s) and not those of the institute. Research disseminated by IZA may include views on policy, but the institute itself takes no institutional policy positions.

The Institute for the Study of Labor (IZA) in Bonn is a local and virtual international research center and a place of communication between science, politics and business. IZA is an independent, nonprofit limited liability company (Gesellschaft mit beschränkter Haftung) supported by the Deutsche Post AG. The center is associated with the University of Bonn and offers a stimulating research environment through its research networks, research support, and visitors and doctoral programs. IZA engages in (i) original and internationally competitive research in all fields of labor economics, (ii) development of policy concepts, and (iii) dissemination of research results and concepts to the interested public. The current research program deals with (1) mobility and flexibility of labor markets, (2) internationalization of labor markets and European integration, (3) the welfare state and labor markets, (4) labor markets in transition, (5) the future of work, and (6) general labor economics.

IZA Discussion Papers often represent preliminary work and are circulated to encourage discussion. Citation of such a paper should account for its provisional character. 
IZA Discussion Paper No. 59

September 1999

\section{ABSTRACT}

\section{Canadian Immigration Experience: Any Lessons for Europe?}

This paper reviews and analyzes the effects of Canada's post World War II immigration policies with the perspective of what European policy makers can learn from this experience. Impact of Immigration on natives' employment and earnings, as well as, immigrants' labor market experiences are discussed. The advantages of Canada's equal share rule of the allocation of immigrant visas are argued. The importance of language skills for economic integration and success is also stressed. The importance of the right human capital mix and experience are found to be needed to guarantee positive labor market outcomes in the host country.

JEL Classification: J15, J61, J68

Keywords: Immigration policy, labor outcomes, assimilation

Prof. Don J. DeVoretz

Co-Director: RIIM

Simon Fraser University

Burnaby, B.C., V5A 1S6, Canada

(604)-291-4575 (Voice)

(604)-291-5336 (Fax)

E-mail: devoretz@sfu.ca 


\section{Introduction}

Canada has recently embarked on extensive six year research program to investigate the economic, social, physical and educational impacts of immigrants to its three major cities. It is important to point out that this major research effort was only begun after Canada received several million immigrants in the post war period. The economic motivation for and economic consequences of this substantial intake no doubt varies by historical epoch but what is most interesting to observe is that this substantial inflow took place with little substantive research or policy analysis. Until the 1990's only one book of substance was written by A. Green (1976) to analyze the post war immigrant economic experience in Canada. It could be argued that the economic benefits from immigration were so obvious that at least until the mid-1970's that immigration policy was set with little critical economic analysis.

Figure 1 Canada's Historical Immigration Flows

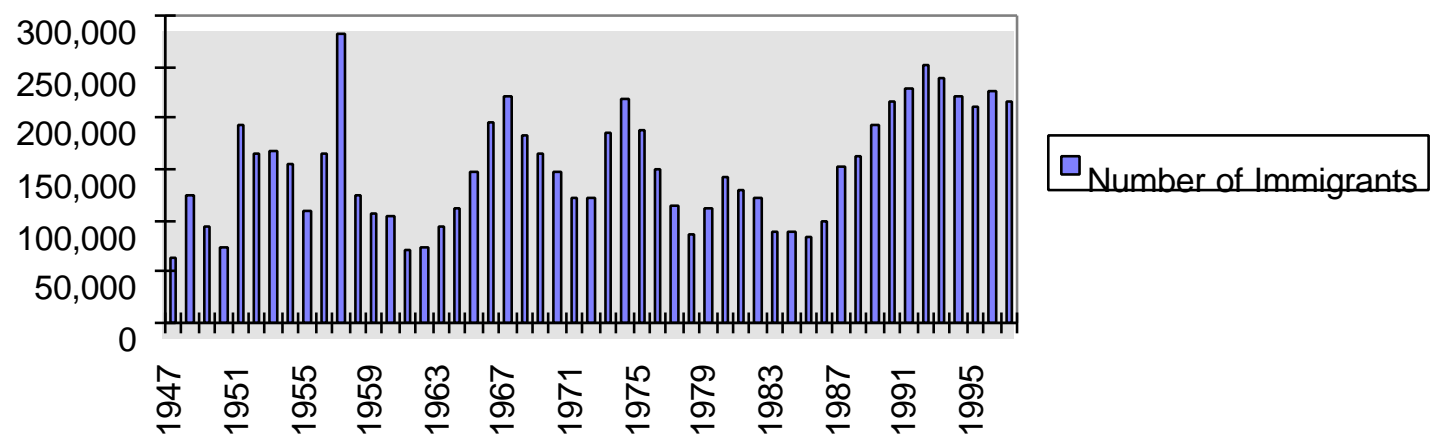

An inspection of Figure 1 allows some stylized facts to emerge form Canada's recent history. First, wide fluctuations occur in the gross immigrant inflow to Canada in terms of absolute admissions. Immigration in the post-war period (i.e. 1947-62) was a product of post war European refugee resettlement coupled with family reunification. This flow was large by Canadian historical standards-often exceeding $1 \%$ of Canada's base population however, return migration is apparently substantial. ${ }^{1}$

The modern immigration period begins in 1967 when a new policy is introduced. Gross immigration flows in 1967 were again high, over 220,000 or more than 1 per cent of the base population. However, throughout most of the modern period (i.e. 1967-86) a secular decline occurred in Canadian immigration

\footnotetext{
${ }^{1}$ The estimated yearly outlflow ranges from 50 to 70 thousand.
} 
flows with important sub-peaks in 1975/76 and 1980. Finally, by the early 1990's immigration levels rose to over 250,000 (1994) equally divided into economic and other (family reunification) entrant classes. By 1998 the total inflows were again below 200,000.

\section{Immigration Policy}

This section focuses on Canada's modern immigration policies (1953-99) in order to rationalize the immigration trends depicted in figure 1. Our discussion emphasizes the relevant policy tools which in particular screened immigrants for their possible economic contribution. Our central aim is to argue that Canada's immigration policies, regardless of era or government in power, were largely designed to be highly selective with respect to the economic attributes of the economically assessed (i.e., independent, business, and assisted relatives) immigrants. Entry through other gates (i.e. family reunification, nominated relatives or refugees) implied less stringent or no economic criteria and when these entry classes grew forces .

Canada's immediate post war immigration policies were still under the regulations of the 1911

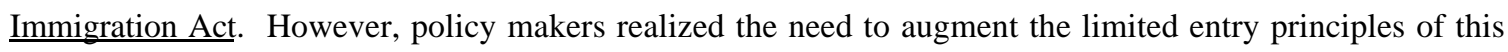
dated act and by 1953 new legislation which still contained racist selection procedures was put into law. The 1953 Immigration Act as enacted, was initially permissive in terms of economic qualifications and total numbers admitted into Canada but, restrictive in terms of the admissible source countries. However, this early policy is important to understand for at least two reasons. First, the 1953 Immigration Act remained essentially in place until the mid-1970's, albeit with substantial changes in its regulations. Moreover, the regulations derived from the 1953 Immigration Act were the central screening devices used to select the majority of the immigrant stock resident in Canada until the late 1980's. In short, the econometric work of the 1980's and early 1990's reported extensively later in this essay is based on a foreign-born stock who largely entered under the $1953 \underline{\text { Immigration Act. }}$

In many ways the 1953 Immigration Act reaffirmed Canada's historical position of tailoring immigration policies to meet Canada's economic and social absorptive capacity. This concept of absorptive capacity implied that an immigrants should be able to immediately enter the labor market and specific countries were identified as preferred areas to produce these immigrants. The United Kingdom, western 
Europe, and the United States were cited as desirable source countries under the 1953 Immigration Act. Hence, the majority of immigrants came from these limited source countries 1960.

These absorption problems were not defined as economic ones, however. Rather, language, customs, and general social mores were the factors most often cited as absorptive criteria. Hawkins (1991: 38) states that the 1953 Act: "gave the governor-in-council the all embracing power to refuse admission on the basis of...peculiar customs, habits or modes of life,[...][ and ] probable inability to become readily assimilated". Throughout the 1950s, economic forces were present to remove this preoccupation with social absorption. Green (1976) argues that the post war economic boom and the resulting demand for skilled workers required a more liberal immigration policy in terms of source countries.

Prior to 1968 the racist elements of the 1953 Immigration Act are self-evident in source country selection. The preferred areas by law-United Kingdom, western Europe and the United States accounted for, on average 42 per cent of the movers in the 1950s. By contrast, under the act the non-preferred regions (Africa, Asia, Australia, Other North-except USA- and Central America, South America, and Oceania) were permitted to send (on average) 7 per cent of the immigration flow between 1950 and 1968. Even with the changing economic forces (Green 1976) and growing political pressures (Hawkins 1991) Europeans as late as 1962 had a great advantage over non-Europeans since they could sponsor a wider range of kin. However, the source countries within Europe were changing. By the late 1950's Italians from the Mezzogiorno and unemployed or displaced central Europeans entered the flow. Nonetheless, until 1967 United Kingdom, northwest Europe and the United States still provided over 50 per cent of Canada's immigrants.

In 1967, a point system was adopted to allow immigrants to Canada to be chosen on the basis of their ability to meet Canadian labour market needs while minimizing discrimination inherent in selection with respect to religion, race, or country of origin. In 1967, Canada's immigration policy became truly universalistic when the restriction on sponsorship of Asian relatives was dropped. Since then, regardless of country of origin, the method of assessment has been applied equally world-wide. This policy has been termed an open policy since the country of origin is not an entry criterion (Marr and Percy:62). The primary applicant in the independent or economic category needed circa 1967 fifty points or more earned from certain economic and demographic characteristics. These attributes included age, education, language, 
occupational demand, skill level, arranged employment, and province of final destination in Canada. In fact, as Coulson and DeVoretz (1993) note: 'During the 1967-1974 period over 50 per cent of the required 50 points could be earned exclusively by the human capital measures of age, education, and language'. This policy shift did not take place in a vacuum. Other major immigrant receiving countries, especially the United States, admitted a large number of immigrants with human capital (Grubel \& Scott 1965). Nonetheless, in contrast to the United States hemispheric quota system, Canada's point system was especially well designed to screen for the potential highly trained immigrant. Canada's point system was biased toward human capital criteria and accelerated the flow of Third World highly trained movers to Canada. This bias ultimately led to accusations that Canada was accelerating the brain drain from Third World countries (DeVoretz \& Maki 1980). In fact, during the $1967-86$ period the total flow of human capital at 1995 replacement costs was over $\$ 30$ billion from all source regions (Coulson and DeVoretz, 1993).

As already noted the open immigration policy since post-1967 with its point system resulted in a substantial change in the composition of immigrants, with a rise in the flow from less developed countries. But this changing source country composition also occurred in Australia and the United States. In later periods -post 1975 for the United States and post 1980 for Australia-Third World-sourced regions dominated these countries' immigrant inflows. These world wide trends point to two underlying forces. First, as economic conditions improved in Europe, the supply of European immigrants declined not just to Canada, but to all destination regions. Next, Canadian policy, namely the point system, had a strong influence on their occupational or skill mix of the immigrant flow. For the 1968-76 period over 73 per cent of all immigrants were directly screened by the point system (covering independents and nominated relatives) with 25 per cent or more being judged as qualified professionals. 


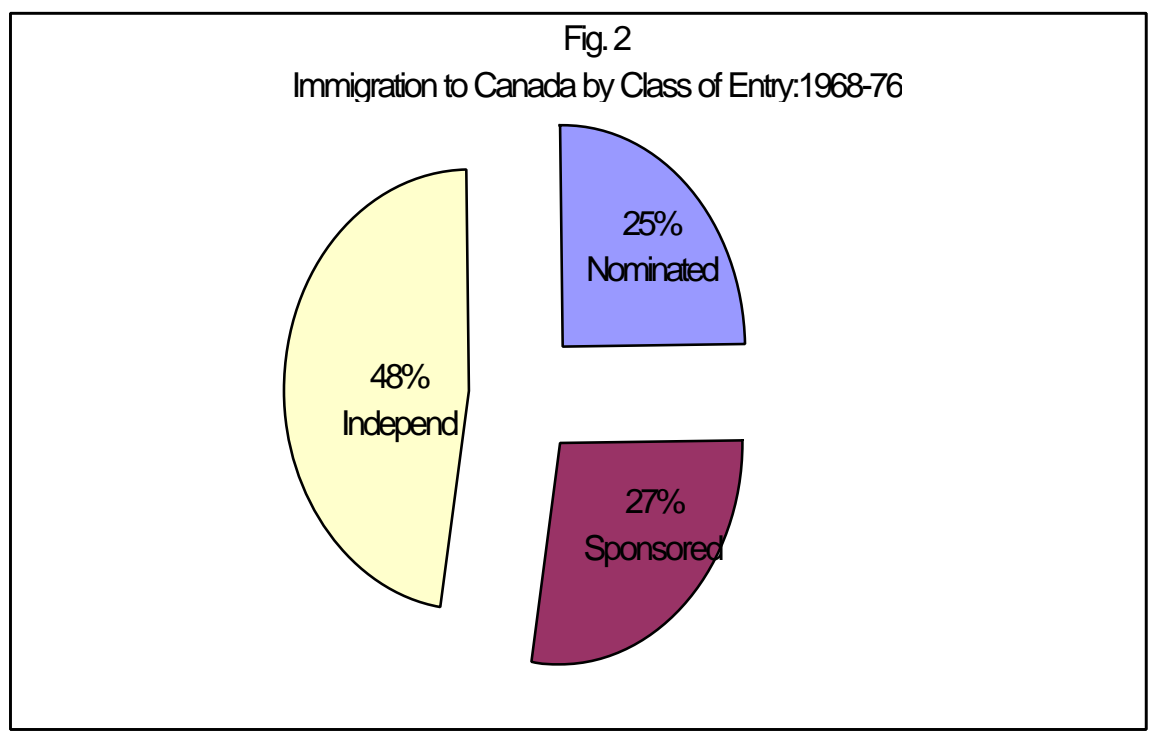

Notwithstanding the apparent early success of the post-1967 regulations, several criticisms were raised about the point system, resulting in the 1974 publication of a government 'white paper' on immigration (i.e. Marr \& Percy 1985). Its authors argued that the anticipated macro economic gains from immigration could not be documented. According to these critics, the presumed scale economies associated with a larger population were apparently not arising under expanding immigration. These critics further argued that if scale economies were sought they could be better achieved through free trade. In addition, some politicians noted that there was no precise immigrant control mechanism in the form of a yearly quota or target. Hence, a yearly immigrant target level and a greater policy emphasis on specific labor market

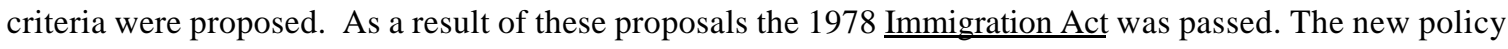
set three major goals for immigration: immigration targets should meet Canadian demographic needs; foster family reunification, and be tied to Canadian labor market requirements. In comparison to the 1967 regulations, the $1978 \underline{\text { Immigration Act }}$ could be termed a restrictive policy at least with respect to the independent or point-screened entry class. Other restrictions inherent in the 1978 act included specific yearly immigrant target levels to be tabled in the House of Commons.. Immigrant entry under the $\underline{1978}$ $\underline{\text { Immigration Act }}$ and in subsequent revisions could now occur via three main avenues: family reunification (family class); refugee class (convention refugees or designated class); or as a economic mover (assisted relative, entrepreneur, self-employed, investor or independent). 
Assessment in each entry class reflected varying degrees of scrutiny for possible labor market impacts. In particular, the 1978 policy linked entry into Canada under the independent class almost solely to labor market requirements. In addition, in periods of high unemployment economic immigrants in the independent group were reduced to nil by the imposition of an occupational bar. If occupational demand were deemed to be zero due to high unemployment in that particular occupation then the number of total points received under all other criteria by the perspective immigrant became irrelevant for admission. In short, adequate occupational demand became a necessary but, not a sufficient criterion for entry under the independent class. For example, during the recession years 1982 through 1985, entrance to Canada under the independent worker category was prohibited, except in the case of arranged employment. Arranged employment required certification from a Canada Employment Center which, in turn, required the employer to demonstrate that she/he had been $\underline{\text { unable }}$ to engage a Canadian citizen. The emphasis under the 1978 act and its subsequent regulations for independent immigrants moved from formal educational qualifications to explicit employment prospects. Coulson and DeVoretz (1993) noted that the 1978 Immigration Act revised the economic criteria from a human capital framework to a manpower planning one. Now for entry as an independent immigrant only 25 per cent of the (increased) seventy total points required for admission could be earned through the human capital attributes of age, education and experience.

The 1978 policy clearly cannot be termed an open one. Rather, it reflected the view that scrutiny was required to insure that immigration costs did not exceed benefits (Marr \& Percy: 58). However, two contradictory forces appear in the 1978 policy which changed the labor market impacts of the post-1978 immigrant flow. First, the post-1978 emphasis on job certification potentially reduced the possibility of short term unemployment for the independent class or points-assessed immigrants. On the other hand, expansion of the family reunification class after 1978 partially circumvented the job certification criterion for entry and opened the possibility of substantial negative economic impacts on wages and jobs. Moreover, the phenomenon of chain migration could arise under the 1978 Act with the total number of family reunified members being infinite over a long enough time horizon. An illustration will make this clear. In the first round, the original points assessed independent immigrant could sponsor his spouse and his parents. His parents could in turn could sponsor the original immigrant's under nineteen year old brothers and sisters. 
These minor children, who are siblings of the original immigrant, could marry a foreign-born person prior to arrival and sponsor them and repeat the process ad infinitum. The family and siblings of the spouse of the original points assessed immigrant could also repeat the process. Thus, two possible infinite chains could arise.

In sum, the 1978 Immigration Act substantially altered the gateways to enter Canada. As noted for the 1968-76 period (under the 1967 regulations of the 1953 Immigration Act) over 70 per cent of immigrants were screened in the independent class. This per cent dropped under the $1978 \underline{\text { Immigration Act }}$ at first below 30 per cent (1975-82) and then to about 14 per cent of the total flow by the mid-1980's. To partially counteract this decline in the independent entry class, new entry classes were devised under the 1978 act. Self employed or entrepreneurs and investor (after 1985) classes were now separately assessed on their ability to be self financed or to create jobs. By the late 1980s these new categories in total represented 9 per cent of all movers.

A collapse in the economic performance of post 1985 immigrants and dissatisfaction with the inability to control the size of particular entry gates i.e. family reunification and a host of other post entry legal problems led to a one year review of current immigration regulations in 1998. One hundred and seventy-two new regulations were proposed and reflect contemporary concerns over the state of the current selection process. The proposed regulations raise the entry requirements. In particular, all immigrants under this proposed legislation are to have functional knowledge of an official language (English/French) prior to entry. The complex points system is to be abolished and replaced with a simplified set of human capital criteria for independent immigrant assessment. The often abused investment class would be restructured with all required monies placed in government trust funds. Finally, sponsorship of family class immigrants would require a substantial threshold income and the signing a legally binding contract by the potential sponsor.

In sum, these major policy changes from a closed (1953 to 1967) to open (post-1967) and then, increasingly restrictive immigration policy (after 1978) are strong a priori reasons to expect structural changes in the economic impact of Canadian immigrants over our study period. However, regardless of how many policy variations may appear over our study period the effectiveness of these changes must still be 
demonstrated. By taking successive economic snapshots during each immigrant policy regime we may detect if structural breaks actually occurred in each policy sub period. With the aid of census data, economic profiles for representative foreign-born and Canadian populations will be made for 1971, 1981 and 1996. The following Tables (1 to 3 ) report the important demographic and economic variables for each selected year's population by birth status. Next, each table reports (in columns 4 and 5) similar attributes but now for only the economically active (aged 25 to 65 ) groups who entered the labor force.

Table 1

Social and Economic Attributes by Place of Birth: 1996

\begin{tabular}{lllll}
\hline All Canadian & All Foreign & Variables & Econ. Canadian & Econ. Foreign \\
\hline 2.94 & 3.07 & Family Size & 2.87 & 3.08 \\
37.18 & 41.86 & Age & 40.55 & 43.06 \\
30.90 & 32.01 & Hours Worked & 33.73 & 33.50 \\
40.34 & 40.99 & Weeks Worked & 43.23 & 42.42 \\
$\$ 28,036.63$ & $\$ 28,838.88$ & Total Income & $\$ 32,467.10$ & $\$ 30,636.07$ \\
$\$ 23,071.24$ & $\$ 23,347.75$ & Wages \& Salaries & $\$ 27,058.82$ & $\$ 25,287.07$ \\
$\$ 1723.44$ & $\$ 2073.31$ & Self Employment Income & $\$ 2048.89$ & $\$ 2214.45$ \\
$\$ 698.10$ & $\$ 877.90$ & Investment Income & $\$ 741.75$ & $\$ 831.43$ \\
$\$ 90.42$ & $\$ 127.69$ & OAP & $\$ 7.52$ & $\$ 9.47$ \\
$\$ 201.72$ & $\$ 241.90$ & CPP & $\$ 146.06$ & $\$ 136.68$ \\
$\$ 746.75$ & $\$ 606.62$ & UIC & $\$ 843.76$ & $\$ 646.11$ \\
$\$ 498.92$ & $\$ 518.84$ & Other Govt. & $\$ 523.75$ & $\$ 517.05$ \\
$\$ 1849.06$ & $\$ 1864.28$ & Total Govt. & $\$ 1903.30$ & $\$ 1722.19$ \\
\hline
\end{tabular}

Notes:

a. Exceeds payments in rows $9-12$ because of wider census definition.

Source: 1996 Canadian Population Census, PUST Microdata.

The first two columns in Table 1 report the average characteristics of the entire 1996 stock of Canadian and foreign-born populations respectively unfiltered for labour force participation. Columns four and five present similar information for the 1996 economically active populations by foreign- birth status. To more accurately detect structural breaks in Canada's immigrant population over time, it is more meaningfully to concentrate on active labour force participants as reported in the last two columns. The economically active foreign-born earned \$1,831 less circa 1996 than their Canadian-born cohorts. This is no doubt due to (among other factors) the fact that the immigrant stock worked slightly less per week and almost one week less per year. The last row in any column indicates any population's total draw on the federal treasury. For 
example, the economically active foreign-born group used \$1722 in federally financed pensions (OAP, CPP), unemployment insurance (UI), and family allowance (fam allow) and other programs. By contrast, the Canadian-born cohort used more $(\$ 1,903.30)$ of these services.

The foreign-born and Canadian-born populations in general (columns 1 and 2) reveal two further trends circa 1996. The entire foreign-born population is much older (41.8 versus 37.1) and earns $\$ 802.00$ more $(\$ 28,838$ versus $\$ 28,036)$. These two factors cause the foreign-born to consume more public services (\$1864 versus \$1849).

Table 2

Social and Economic Attributes by Place of Birth: 1981

\begin{tabular}{lllll}
\hline All Canadian & All Foreign & Variables & Econ Canadian & Econ Foreign \\
\hline 3.44 & 3.10 & Family size & 3.29 & 3.36 \\
30.16 & 43.24 & Age & 40.81 & 43.1 \\
21.7 & 22.5 & Hours work & 34.32 & 39.82 \\
31.79 & 41.1 & Weeks worked & 46.90 & 47.2 \\
$\$ 7962$ & $\$ 11,110$ & Total income & $\$ 22,647$ & $\$ 23,075$ \\
$\$ 6092$ & $\$ 8251$ & Wages \& Salaries & $\$ 18,896$ & $\$ 19,400$ \\
$\$ 483$ & $\$ 719$ & Self employment income & $\$ 2,110$ & $\$ 2,077$ \\
$\$ 516$ & $\$ 609$ & Investment Income & $\$ 821$ & $\$ 937$ \\
$\$ 303$ & $\$ 609$ & OAP & $\$ 8.22$ & $\$ 4.37$ \\
$\$ 74$ & $\$ 102$ & Family allowance & $\$ 308$ & $\$ 300$ \\
$\$ 135$ & $\$ 111$ & UIC & $\$ 226$ & $\$ 154$ \\
$\$ 153$ & $\$ 160$ & Other govt & $\$ 93.79$ & $\$ 59.90$ \\
$\$ 665$ & $\$ 982$ & \$Total Gov't & $\$ 636$ & $\$ 518.27$ \\
\hline
\end{tabular}

Source: 1981 Canadian Population Census, microdata

In 1981 we observe in table 2 the structural effects owing to the different immigration flows which pre date the 1978 Immigration Act. For an earlier period -1981- two changes appear in the respective stocks of economically active foreign-born and Canadian-born populations. The foreign-born worked more hours per week (5) in 1981 than the Canadian-born and this greater effort in the labour market yields a slightly larger income $(\$ 1,064)$ or wages and salaries $(\$ 504)$. In contrast to 1996, the greater 1981 earning power of the foreign-born stock resulted in the foreign-born using substantially fewer public services $(\$ 518.27)$ than the Canadian-born-headed household (\$636.01). 
Table 3

Social and Economic Attributes by Place of Birth: 1971

\begin{tabular}{lllll}
\hline All Canadian & All Foreign & Variables & Econ Canadian & Econ Foreign \\
\hline 2.24. & 2.17 & Family size & 2.24 & 1.79 \\
27.91 & 43.15 & Age & 42.15 & 48.89 \\
21.7 & 22.5 & Hours work & 34.32 & 39.82 \\
22.7 & 20.7 & Weeks worked & 43.5 & 39.50 \\
$\$ 2,481$ & $\$ 3,945$ & Total income & $\$ 5,758$ & $\$ 4,362$ \\
$\$ 1,976$ & $\$ 3,010$ & Wages \& Salaries & $\$ 4,577$ & $\$ 4,362$ \\
$\$ 181$ & $\$ 308$ & Self employment income & $\$ 444$ & $\$ 466$ \\
\hline
\end{tabular}

Source: 1971 Canadian Population Census, microdata

In 1971, we would anticipate a relative collapse in the value of the of reported economic variables given the limited economic scrutiny of this older vintage of immigrants which were scruitinized under the 1953 Immigration Act. This is borne out by the descriptive data in Table 3. Economic disadvantages for the economically active foreign--born clearly appear in 1971. Even though the average foreign- born head of household worked almost 5 more hours per week and 7 weeks more a year then their Canadian-born counterpart, they earned \$215 less in wages and salaries and \$1396 less in total income than Canadians.

This review of the 1971-96 census data reveals two important points. First, only in 1981 did the economically active foreign--born earned more than the Canadian-born in the labour force. Moreover, by 1996 the foreign-born households consumed more public services than the Canadian-born average. In sum, the economic performance of Canada's immigrant population varies substantially across policy epochs.

\section{Impacts of Immigrants in the labor market: A theory}

The flows of immigrants as described in tables 1-3 altered employment portunities and wage rates for Canadians and have been a rich source of policy debatres over the last thriy years. For example, the earlier cited Immigration Act of 1978 was derived from a 'Canada First' policy which closely tied immigration to unemployment and vacancy rates (Marr and Percy 1985). Several regulations were enacted to limit the size and job displacement effect(s) presumably derived from this independent immigrant category. In sum, the period 1975-84 reflected an almost myopic concern with the issue of labour substitution. During a most recent period, 1985-95, another shift in immigrant policy occurred reflecting a new view of the role of 
immigration and job creation. This led to the addition of new and explicit business and entrepreneurial immigrant entry classes. The 1985 Annual Report of Immigration Canada, stated explicitly the, then, governments view on labour substitution: 'The federal government does not accept the popular misconception that immigrants take jobs away from Canadians. Immigrants contribute to economic growth and job creation by augmenting capital formation.' (1985:1). By 1999 current government policy again views certain immigrants as sources of wage compression and unemployment.

Thus, in a twenty three year immigrant policy period (1976-99) various governments have offered two conflicting hypotheses with respect to labour substitution; immigrants either create jobs, or they take jobs. We now turn to the task of formally testing the employment/ wage hypotheses.

To analyze the displacement or wage compression issues arising from immigration, elasticities of substitution between immigrant labour and Canadian-born labour must be computed from a production function which has been specified for all relevant Canadian industries. To clarify the estimating procedure a theoretical exposition of the displacement phenomenon follows.

Figure 3: Theoretical Labor market wage and displacement
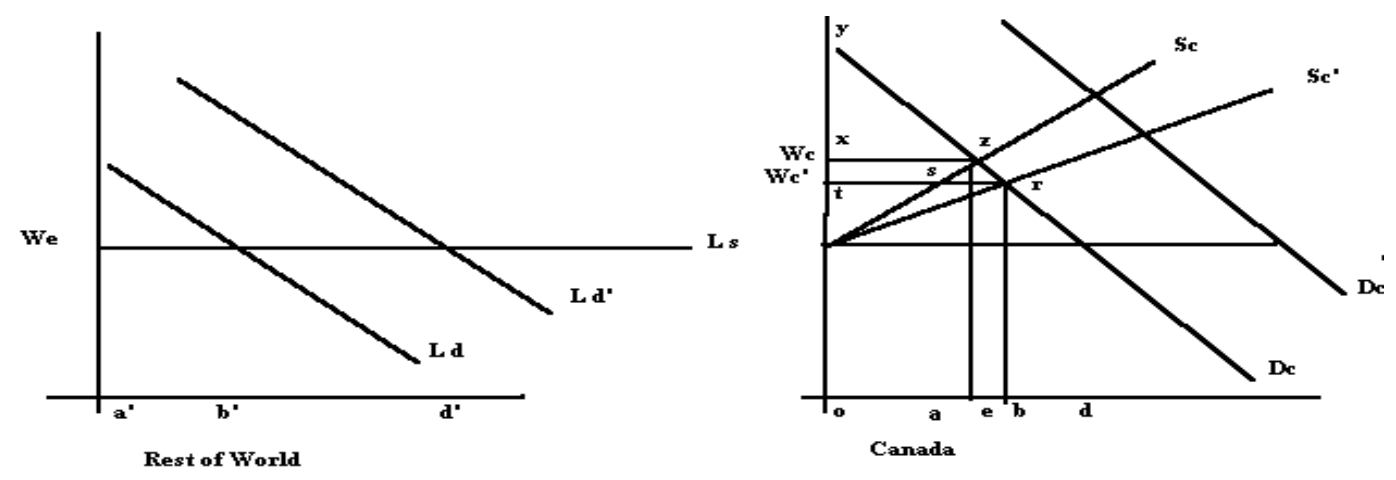
Consider an immigrant receiving country that produces a single, non-exported output, by means of two inputs, capital, and homogeneous labour. The left panel of Figure 3 resents a situation in which the world supply of labour is perfectly elastic at wage rate (We). ${ }^{2}$ The right panel shows the labour market in the immigrant receiving country, i.e. Canada. If labour were to seek its maximum earnings, with negligible transportation and other costs, and with no institutional impediments, then, (od) workers would migrate to Canada. Thus, the Canadian labour supply would consist entirely of the foreign born and its wage rate would fall to the world equilibrium level, or, (We). On the other hand, if Canada closed its borders, the wage rate in Canada would be (Wc). In addition, if independent events such as a rise in product price or increased complementary capital appeared in the economy, then these supply shifts induced by shifts to $\mathrm{Sc}^{\prime}$ ) the original equilibrium wage Wc would rise to Wc with a shift in the demand curve equal to Dc'. This would result in no domestic labour displacement and a rising wage rate.

Under a more realistic scenario for Canada immigrants arrive under a binding quota of $\left(a b=a^{\prime} b^{\prime}\right)$ workers, thus an increase in the labour supply from $(\mathrm{Sc})$ to $\left(\mathrm{Sc}^{\prime}\right)$ would result. In particular, this restraint on immigration appears appropriate for Canada after 1978 (Akbar and DeVoretz 1993). Now this limited increase in immigration, (ab), would have two important labour market consequences. First, the domestic wage rate would fall to $\left(\mathrm{Wc}^{\prime}\right)$, and total employment would rise from (oe) to (ob). However, domestic employment declines from (oe) to (oa). Thus, immigrants displace domestic workers by the amount (ae). Second, when the wage rate falls from $(\mathrm{Wc})$ to $\left(\mathrm{Wc}^{\prime}\right)$, labour earnings change from (oxze) to (otrb), of which (otsa) accrues to Canadian-born workers and (asrb) to immigrants. The earnings of Canadian-born workers have fallen from (oxze) to (otsa). On the other hand, returns to non-labour inputs or capital, have risen from (xyz) to (tyr). Hence, in this intermediate case Canadian capital owners benefit from immigration, while others, native-born labour, are injured. Finally, the existing wage differential of (Wc'-We), relative to the immigrant's opportunity cost is no doubt, substantial. Given such a substantial wage differential, a queue would form with immigrant applications exceeding yearly available slots.

The actual wage and employment changes resulting from any immigration flow depend upon the domestic elasticities of labour demand and supply, the magnitude of the quota, and other assumptions

\footnotetext{
${ }^{2}$ Perfect elasticity implies that within a relevant range all the labour demanded will be supplied at the prevailing wage $\mathrm{W}_{\mathrm{e}}$.
} 
implicitly embedded in figure 3. For example, the more inelastic the demand and supply relationships, the greater will be the reduction of domestic wages due for any given amount of immigration. Moreover, the displacement effect will be greater, the more elastic is the labour supply and the less elastic is labour demand.

\section{Impacts of Immigrants in the labor market: Canada-wide}

Akbari and DeVoretz estimate a translog production function to capture the substitution elasticities across various vintages of immigrants and Candians with at first 1980 data to reflect the pre-1978 immigration policy. ${ }^{3}$

Table 4

Elasticities of Factor Complementarities: 1980 125 Canadian Industries

\begin{tabular}{lccc}
\hline Elasticity & Value & Std. Error & t-value a \\
\hline Between Cdn-born and earlier immigrants (Cn,b) & -0.41 & 1.10 & -0.37 \\
Between Cdn-born and recent immigrants (Cn,d) & -0.41 & 2.46 & -01.7 \\
Between Cdn-born and capital (Cn,k) & 0.98 & 0.43 & $2.28^{*}$ \\
Between earlier and recent immigrants (Db,d) & 1.45 & 9.39 & 0.15 \\
\hline
\end{tabular}

Notes:

a) A single asterisk indicates significance at the .05 level of significance.

Source: Akbari and DeVoretz (1992)

Table 4 reports the estimated elasticities of complementarity. For convenience, pre-1971 immigrants are termed earlier immigrants, and those arriving later termed recent immigrants. This distinction between immigrant vintages is an attempt to explicitly recognize the hypothesis that the two immigrant pools

\footnotetext{
${ }^{3}$ Akbari and DeVoretz (1992) offer the following implicit production function to estimate labour substitution in Canada: $Y i=f(K i, N i, B I i, D I i)$

where:

$Y i=$ Value added in industry $\mathrm{i}$.

$K i=$ Capital stock in industry $\mathrm{i}$.

$N i=$ Employed labour in industry i aged 15 years and over who were born in Canada.

$B I i=$ Employed labour in industry $\mathrm{i}$ aged 15 years and over who were born abroad and migrated to Canada prior to 1971.

$D I i=$ Employed labour in industry i aged 15 years and over who were born abroad and migrated to Canada after 1971.
} 
are drawn from different populations. The corresponding policy issue which is being addressed is the effect of the 1967 immigration regulations. As noted in above only after 1967, did Canada truly employ a universalistic point system which did not discriminate by country of origin. We test to see if these policy regulations resulted in varying degrees of labour substitution vis a vis earlier or more recent immigrants.

It is observed from Table 4 that the elasticities of substitution between Canadian-born workers and earlier immigrants as well as between Canadian-born workers and recent immigrants are negative. This negative elasticity value implies that immigrant labour substitutes for Canadian-born labour. However, the corresponding t-values indicate that the elasticity coefficients are not statistically significant at the .05 level. Hence, the hypothesis that there is no displacement of Canadian-born workers by immigrants can be accepted for both the earlier and recent immigrant flows. Furthermore, it is also important to note that both the earlier and recent immigrants' affect the employment of Canadian-born to the same extent (the elasticity values are identical). The hypotheses that the pre and post-1971 immigrant pool have differential substitution effects with respect to the Canadian-born labour force must be rejected. Thus, circa 1980, there is no evidence to support the economy-wide displacement hypothesis or that immigrants were capital using. Critics often dismiss these economy wide findings for Canada and cite examples of displacement in specific vunerable sectors. In other words, the critics argue that the above economy-wide findings may conceal substitution by subsectors. Thus, by disaggregating these economy-wide tests it may be possible to reverse these economy-wide findings in certain sub-sectors. We now turn to this task.

\section{Displacement in foreign-born intensive industries}

The most obvious tactic to detect any significant substitution effect is to select those entry level industries with a high concentration of foreign-born under the supposition that more foreign-born in the labour force would cause more substitution. A highly concentrated foreign-born industry is defined as any

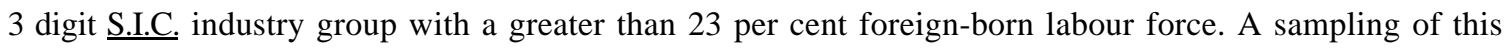
subset of industries appears in Table 5. 
Table 5

Ratio of Foreign-born to Total Labour Force

Selected Largest Canadian Industries: 1980.

\begin{tabular}{lccc} 
Description & SIC \# & Absolute \#(000s) foreign-born & per cent of foreign-born \\
\hline Meat and Poultry & 101 & 12.7 & 28 \\
Bakery & 107 & 12.3 & 30 \\
Food (Misc) & 108 & 10.6 & 27 \\
Plastics and Fabricating & 165 & 11.2 & 32 \\
Men's Clothing & 243 & 19.0 & 45 \\
Women's Clothing & 244 & 21.0 & 51 \\
Household Furniture & 261 & 13.6 & 34 \\
Universities \& Colleges & 806 & 39.0 & 31 \\
Hardward tool \& cutlery & 306 & 9.2 & 38 \\
Metal Stamping & 304 & 10.0 & 29 \\
Machine Shops & 308 & 7.5 & 32 \\
\hline
\end{tabular}

Several features of these selected industries are important to note. First, although many of the selected 59 industries are characterized by an unskilled labour force using labour intensive techniques (e.g., bakeries, clothing, and food processing) many groupings are highly skilled (e.g. Universities , machine shops, metal stamping.) Thus, no generalization about skill content appears a priori for this sub-set of industries other than the pre-selected degree of concentration of foreign-born workers. Why a heavy concentration of foreign-born workers in this bizarre set of industries would cause displacement is open to speculation. One implicit hypothesis is that the job vacancy criteria under the 1978 Immigration Act may have been inappropriately applied (DeVoretz 1995) or that members of the family reunification class entered some or all of these foreign-born labour intensive industries.

Table 6

Elasticities of Factor Complementary: Above Average Foreign-born Intensive Industries: 1980

\begin{tabular}{lccc}
\hline Elasticity between: & Value & Std. Error & t-value $^{\mathbf{a}}$ \\
\hline Canadian-born - earlier Immigrants(Cn,b) & -.67 & .33 & -9.3 \\
Canadian-born - recent Immigrants (Cn,d) & -.67 & .25 & -2.68 \\
Canadian-born - Capital (Cn,k) & 1.08 & 1.35 & .8 \\
Recent Immigrants - Capital (Cd,k) & 1.02 & .65 & 1.57 \\
Earlier - Recent Immigrants (Cb,d) & .28 & .21 & 1.33 \\
\hline
\end{tabular}

Notes: a) A single asterisk indicates significance at the .05 level of significance.

Source: Author's calculations 
Table 6 reports the calculated elasticities of complementarity and associated test statistics for the foreign-born intensive industrial groupings. One result is obvious. Now, in these industries both recent $(\mathrm{Cn}, \mathrm{d})$ and earlier immigrants $(\mathrm{Cn}, \mathrm{b})$ are significant substitutes for Canadian-born labour. Also, capital is still not a significant complementary input $(\mathrm{Cn}, \mathrm{k})$ to either recent or earlier immigrants. Finally, earleir arrivals and more recent immigrants $(\mathrm{Cb}, \mathrm{d})$ are not substitutes for one another. These findings are in sharp contrast to the Canadian economy-wide results reported in Table 4.

Given the above results the actual degree of displacement between Canadian-born and foreign born workers can be calculated for this subset of 59 foreign-born intensive industries. For example, in the meat and poultry, clothing, and University industry groups the absolute marginal displacement of Canadianborn workers for each one-per cent rise in their immigrant labour force is respectively; 214, 582, 268 Canadian-born.

Clearly, the degree of displacement depends directly upon the labour intensive nature of the industry and the absolute number of Canadian-born workers in the industry. In general, across the preselected 59 industries a one per-cent rise in foreign-born labour would have reduced Canadian-born employment circa 1980 by 2,543 workers.

\section{Displacement in the 1990's}

Immigrant entry crieteria changed after 1981 to reflect the changing regulations under the new 1978 Immigration Act. Most importantly, during the 1980's the pre-dominant entry gate became the family class group which was not assessed for its potential labour market impacts. Thus, the cross-elasticities of the more recent vintage of immigrants could have changed with respect to labour by 1991 . Table 7 indicates that the 1991 results largely replicate the economy-wide findings for 1981. 
Table 7

Elasticities of Factor Complementarities: 1991

107 Industries

\begin{tabular}{lccc}
\hline Elasticity & Value & Std. Error & t-value $^{\mathbf{a}^{\mathbf{2}}}$ \\
\hline Between Canadian-born - earlier immigrants & -0.97 & .48 & -0.47 \\
$(\mathrm{Cn}, \mathrm{b})$ & & & \\
Between native-born - recent immigrants $(\mathrm{Cn}, \mathrm{d})$ & .96 & 1.05 & 1.01 \\
Between native-born - capital (Cn,k) & 0.91 & 1.02 & $1.93 * *$ \\
Between recent immigrants - capital (Cd,k) & 1.03 & 0.97 & 1.00 \\
Between earlier - recent immigrants (Cb,d) & 1.18 & .39 & 0.47 \\
\hline
\end{tabular}

Notes:

a) A double asterisk indicates significance at the .10 level of significance.

Source: Author's calculations.

Only the Canadian-born and recent immigrant elasticity value in the foreign intensive group (unreported) differs significantly between periods. This is, of course, an important exception. Circa 1981 in the foreign-born intensive industries Canadian-born labour and post-1971 immigrant arrivals were significant substitutes. By 1991 this pair had become insignificant complementary inputs. It should be noted that the significant substitution between Canadian-born labour and pre-1971 immigrants held in 1991, as it did in 1981.

This section posed one central question 'Do immigrants displace Canadian-born workers?' and a host of subsidiary questions. We are now in a position to answer these questions. First, economy-wide there is no modern evidence circa 1981 or 1991 that the post-war stock of immigrants significantly displaced Canadian-born workers. In addition, this lack of substitution was invariant to date of arrival. Also, economy-wide, immigrants did not require a significant amount of physical capital upon entry while an expansion of the Canadian-born labour force did. This lack of economy-wide capital complementarity for immigrants, we believe, was a result of the on average high human capital content embedded in Canadian immigrants upon arrival circa 1967 to the 1990’s. (Coulson and DeVoretz, 1993).

If one of Canada's continuing major immigrant policy goals is, in fact, the successful absorption of immigrants into the labour market then, the economy-wide findings indicate that this goal was met. The fact that these conclusions hold for two cross-sectional tests make these results more robust, than they might first appear. First these results reflect the long-term adjustment under several expansionist and restrictive 
policy regimes given that these economy-wide tests incorporate the stock of working immigrants who entered circa 1945 to 1990 . Nonetheless, economy-wide, no labour displacement occurred. However, in the foreign labour intensive industries, significant labour substitution occurred between the foreign-born and Canadian born. A combination of factors, including a greater than average foreign labour content, and a large share of value added attributed to physical capital led to labour displacement in this sector. Equally important, under these conditions it is found that in this foreign intensive sub-sector, recent immigrants required a significant increase in physical capital. Moreover, the foreign intensive industrial sub-group does not conform to the stereotypical view of immigrant entry level industries. In fact, these industries include firms which use unskilled labour intensively, and other firms, which use highly skilled human capital intensively. These two types of immigrant streams reflect the two broad components of the overall immigrant flows which resulted from the post-1967 immigrant policy regimes. Immigrant policies after 1967 simultaneously selected immigrants with a greater level of human capital (1967-73) while later policies (post 1978) expanded the family reunification class reducing human capital (Coulson and DeVoretz 1993). This indicates the inherent policy dilemma of attempting to simultaneously achieve humanitarian and economic goals and avoid labour displacement.

\section{Canadian-born wages and immigration}

Figure 2 clearly indicates that in addition to labor displacement, immigration can lead to higher or lower wages for the resident labor force. For example, two mutually exclusive outcomes for wage and labor displacement appear in figure 2. First, immigration under an expanding labor demand curve leads to greater native-born wages and employment due to the accompanying complementary human capital in the migration flow. In the opposite case both earnings degradation and labor displacement occur in the native-born labor force if immigrants have little complementary human capital. We now turn to the econometric results which sort through these wage outcomes.

A crucial question in the Canadian context is 'Do immigrants compete for jobs with young entry level Canadian workers ?' Laryea (1997) employs an age-cohort technique, developed by Suen (1994) to 
estimate the effects of immigration by age groups on wages. ${ }^{4} \mathrm{~A}$ reoccurring policy question which motivates the age-cohort approach is: what should be the optimal age structure associated with Canada's immigration policy? The 1991 Canadian census reveals that $37 \%$ of immigrants were aged 25 - 44 years at arrival, another $27 \%$ between 15 - 24 years, while $28 \%$ were younger than 15 years of age (Statistics Canada, 1994). In short does this wage structure with a youthful media age of 23.6 years,produce wage compression on the younger resident population?

Laryea (1997) estimated wage equations using 1991 census data by age groups classified into eight five-year cohorts ranging from the 25-29 year-old age group to the 60-64 year-old age cohorts. Individuals were also classified into four groups by birth status: (1) Canadians, (2) early immigrants (those who immigrated to Canada before 1970), mid-vintage immigrants (those who immigrated between 1971 and 1980), and recent immigrants (those who immigrated to Canada after 1981). Given these wage equation estimates Laryea (1997) reports an important simulation exercise which measures the wage impact by age and entry year from a $20 \%$ increase in the number of recent immigrants. The results are summarised in the table 8 .

Table 8

The Impact of a $20 \%$ Increase in the Stock of Recent Immigrants on Wages

\begin{tabular}{lcccccccc}
\hline & $25-29$ & $30-34$ & $35-39$ & $40-44$ & $45-49$ & $50-54$ & $55-59$ & $60-64$ \\
\hline Native Born & $-.079 \%$ & $-.047 \%$ & $-.076 \%$ & $-.102 \%$ & $-.085 \%$ & $-.070 \%$ & $-.047 \%$ & $-.037 \%$ \\
Early Imm & $-.079 \%$ & $-.047 \%$ & $-.076 \%$ & $-.102 \%$ & $-.085 \%$ & $-.070 \%$ & $-.047 \%$ & $-.037 \%$ \\
Recent Imm & $-.086 \%$ & $-.069 \%$ & $-.095 \%$ & $-.120 \%$ & $-.103 \%$ & $-.088 \%$ & $-.066 \%$ & $-.056 \%$ \\
\hline
\end{tabular}

Source: Laryea (1997).

The results show that the wage impacts of a $20 \%$ increase in recent immigration levels on the native-born and other immigrant vintages are minimal regardless of age. The wage decreases associated with this hypothetical inflow is no more than $1 \%$, ranging from $-0.037 \%$ for the native born and early immigrants in the 60-64 year-old age cohort, to a high of $-0.102 \%$ for recent immigrants in the 40-44 year-old age cohort. Part of the reason why these wage impacts are so small can be attributed to the relatively small percentages of

\footnotetext{
${ }^{4}$ This approach estimates a two-stage Constant Elasticity of Substitution (CES) model that aggregates immigrant groups by age cohorts and aggregate cohorts into effective labour, which is used to study the substitution relationships between age cohorts and between immigrant groups. One advantage of this immigrant cohort size approach is that immigrant age cohorts are not mobile at any one point in time.
} 
immigrants making up the total labour force..$^{5}$ Thus economy wide it appears that the wage impacts of immigration flows are minimal and have no adverse impacts on Canadian labour markets.

The absence of significant wage impacts of immigration flows economy-wide can mask the potential outcomes in the various industries in the economy. Estimating wage impacts across industries are also very important because certain industries serve as entry points for immigrants, and immigrants can potentially suppress wages of native-born workers in those industries. (See Seward and Tremblay, 1989). Laryea (1997) estimated a random effects model to examine the impact of foreign-born labour on native-born wages by industry ${ }^{6}$ using panel data form the 1988-1990 Labour Market Activity Survey (LMAS). Laryea (1997) shows that looking at the total sample, and then the male and female sub-samples separately, immigration had a positive impact on the wages of Canadians. The estimated wage elasticities suggest that a $1 \%$ increase in the overall share of foreign-born labour results in a $1.1 \%, 1.3 \%$ and $1.4 \%$ increase in wages for all Canadians, Canadian males and Canadian females respectively. However, when the data was disaggregated by industry, wage suppression was detected in the primary, transportation and storage, and retail and wholesale trade industries. This finding was detected in all 3 samples. The elasticities ranged from a low of $0.6 \%$ in the primary industries for the female sample, to a high of $5.9 \%$ in the transportation and storage industries for the male sample.

These Canadian resutls parallel a German study by De New and Zimmermann (1994) who concluded that immigration had depressed wages of German blue-collar workers and increased the earnings of whitecollar workers in the 1980's. Their econometric evidence implies that a 1 percentage point increase in the overall share of foreign-born labour results in a 4.1 percent reduction in the average hourly wage of all

\footnotetext{
5 . For example, recent immigrants constitute only $3.8 \%$ of the effective labour supply of the $40-44$ year-old age cohort, which in turn make up $18.9 \%$ of the effective aggregate labour supply. 
workers. Furthermore, they also estimated that the wages of blue collar workers would decline by approximately 5.9 percent, but those of white-collar workers would increase by about 3.5 percent

\section{$\underline{\text { 8. Immigrant labor market experience }}$}

To this point this essay has concentrated on the rather benign effects of immigrants on the employment and earnings prospects of resident Canadians and earlier immigrant arrivals. It is clear however, that the underlying theoretical paradigm of the preceding models- a neo-classical view of the labor marketmay hide occupational segmentation of immigrants. In other words, immigrants are isolated in segmented labor markets upon entry and no wage or employment effects occur in mainstream Canadian labor markets. This section reviews the literature of Canadian immigrant occupational segmentation and subsequent wage discrimination. Hiebert (1997) investigates the patterns of occupational distribution by ethnicity in Canada's three major cities: He argues that if immigrants are marginalized into urban ethnically concentrated occupations then this finding would be entirely consistent with limited wage effects or isolated occupational displacement reported on Canada's native-born population as reported above. Hiebert's study provides an index for measuring the degree of ethnic concentration by occupation. This index reports the ratio of the actual to the expected number of immigrants by ethnicity in occupations across Canada's three largest cities.

An example of Hiebert's results for males and females in Vancouver circa 1991 appears in Table 9.

Table 9

Occupation by Ethnic origin for Females in Vancouver: 1991

\begin{tabular}{llllll}
\hline Occupation & British & Jewish & South Asian & Filipina & Vietnamese \\
\hline Manag & 1.2 & 1.3 & .5 & .3 & .6 \\
Law & 1.3 & 3.8 & .3 & .1 & 0 \\
Teacher & 1.3 & 2.6 & .2 & .2 & .1 \\
UnivT & 1.0 & 3.4 & .8 & 0 & 1.3 \\
Clerical & 1.1 & 1.4 & .7 & .2 & 1.0 \\
Sales & 1.1 & 1.4 & .7 & .3 & .6 \\
House & .5 & 0 & 2.7 & 2.4 & 1.2 \\
Labor & 1.2 & 0 & 2.9 & 0 & 0 \\
Taxis & .7 & 0 & 0 & 0 & 0 \\
Nurses & 1.2 & .7 & .5 & .4 & 0 \\
\hline
\end{tabular}

Source: Hiebert (1997), Table 5. 
An index value of unity indicates that an ethnic group's presence in a particular occupation matches its presence in the total population and hence no segmentation. Table 9 reports a near unity value for females of British descent in Vancouver across most occupations except housecleaning (house). On the other hand, Jewish females were over represented in the human capital intensive occupations (law, teaching, University teachers) while South Asian, Filipina and Vietnamese females are underrepresented in managerial. law, teaching and nursing occupations.

Table 10

Occupation by Ethnic origin for Males in Vancouver: 1991

\begin{tabular}{llllll}
\hline Occupation & British & Jewish & South Asian & Filipina & Vietnamese \\
\hline Manag & 1.2 & 1.7 & .6 & .4 & .3 \\
Law & 1.3 & 3.4 & .5 & .2 & .9 \\
teacher & 1.3 & 2.1 & .4 & .2 & .2 \\
UnivT & 1.1 & 8.8 & .5 & .2 & .2 \\
Clerical & 1.0 & .8 & 1.0 & 1.7 & .5 \\
Sales & 1.1 & 1.6 & .9 & .6 & .4 \\
MDs & 1.1 & 8.8 & .5 & .2 & 0 \\
labor & 1.2 & 0 & 1.3 & 0 & 0 \\
taxis & .7 & 0 & 6.1 & .4 & .6 \\
farmers & 1.0 & .2 & 2.4 & .6 & 2.7 \\
\hline
\end{tabular}

Source Hiebert (1997), Table 6

The male occupational patterns by ethnicity reported in Table 10 parallel that of the females in Vancouver. Again, British males are distributed near their expected numbers (i.e. ratio is near unity) while Jewish males are well above unity for the human capital intensive occupations. As with females, Third World male ethnic groups are under represented in these human capital intensive occupations.

Hiebert suggests that the patterns reported in the last 3 columns of tables 9 and 10 represent significant segmentation of the newest immigrant flows. ${ }^{7}$ Finally, Hiebert argues that there is no advantage for ethnic immigrants to migrate between Canada's three major cities since the occupational ethnic patterns are repeated for Toronto and Montreal.

\footnotetext{
${ }^{7}$ Over time there is some evidence that male ethnic immigrants progressively move out of the secondary level jobs. However, for females there exists a double jeopardy in that female immigrants regardless of when they arrived are continuously employed as cleaners (Indo Canadian) and garment workers (Chinese). The daughters of these immigrants when born in Canada however break this pattern.
} 
Pendakur and Pendakur (1996) test for the degree of marginalization of immigrants as revealed by differences between ethnic groups. They test for double jeopardy in the Canadian labor market by first measuring whether immigrants earn less than the foreign-born in Canada when you control for the standard human capital variables of age, education, etc. In addition, they test to see if simple ethnicity matters when you control for all of the obvious human capital characteristics as well as foreign birth status. The results are straightforward. In an uncontrolled environment circa 1991 "there is a $21 \%$ difference in mean lag earnings between visible minorities and whites." Pendakur and Pendakur then estimate the age earnings functions for various combinations of ethnicity and foreign-birth status and perform Oaxaca type comparisons which are reported in Table 11 below.

Table 11

Oaxaca type comparisons by ethnicity in Canada 1991

\begin{tabular}{|c|c|c|c|c|c|c|c|}
\hline Sex & Birth & Ethnic & Canadian & by & Birth & Imm & by Birth \\
\hline \multirow{6}{*}{ Males } & \multirow{4}{*}{ Canadian } & & White & Visible & Aborigine & White & Visible \\
\hline & & White & Compare & $-2 \%$ & $-9 \%$ & $-3 \%$ & $-21 \%$ \\
\hline & & Visible & $-13 \%$ & $-21 \%$ & NA & $-14 \%$ & $-30 \%$ \\
\hline & & Aborigin & $-23 \%$ & NA & $-35 \%$ & NA & NA \\
\hline & Imm & White & $23 \%$ & $14 \%$ & NA & $10 \%$ & $-12 \%$ \\
\hline & & Visible & $10 \%$ & $-2 \%$ & NA & $-10 \%$ & -25 \\
\hline \multirow[t]{5}{*}{ Females } & Canadian & White & Compare & $2 \%$ & $-5 \%$ & -1 & -7 \\
\hline & & Visible & $1 \%$ & $1 \%$ & NA & 0 & -7 \\
\hline & & Aborigin & $-13 \%$ & NA & $-19 \%$ & NA & NA \\
\hline & Imm & White & $7 \%$ & $16 \%$ & NA & -1 & $-2 \%$ \\
\hline & & Visible & $9 \%$ & $18 \%$ & NA & -8 & -10 \\
\hline
\end{tabular}

Source: Pendakur and Pendakur 1996, Table 4

Now with the aid of Table 11 it is possible to deduce the impact of ethnicity and foreign birth status by gender on earnings. The ideal situation in a controlled environment would be to explain all of the male (or female) observed earnings differences by human capital characteristics. However, Table 11 indicates that this is not possible in Canada using Pendakur and Pendakur's earnings equations. For example, the first numerical value in table 11 is $13 \%$ which allows the following interpretation. It suggests that if we gave Canadian born white males the earnings characteristics (education, age, etc.) of the Canadian-born visible minorities then white males earnings would fall only by $13 \%$ of the required $21 \%$ to eliminate the possibility of wage discrimination. In other words $8 \%$ of the $21 \%$ earnings difference between white and visible 
minority males is unaccounted for by human capital characteristics. This $8 \%$ difference is owing to a difference in the earnings structure between ethnic and white earnings functions. What of the immigrants? If you apply immigrant characteristics to Canadian-born males' earnings functions and vice-versa it is possible to deduce the affect of birth status on earnings. For example, exchanging white immigrant characteristics with white Canadian born males leaves only a $3 \%$ difference of earnings in favour of Canadian born whites. However, if you gave the visibility minority immigrant males the characteristics of the white native-born males $21 \%$ (i.e. $-21 \%$ ) is still unaccounted by the earnings structure indicating the degree of discrimination. Moreover, if you observe in the last column in row 4 the value of $-12 \%$ indicates the degree of discrimination between white immigrants and visible minority immigrants if you equip the visible minority immigrants with the characteristics of white immigrants. In short, discrimination as measured in this sense drops but is still large on an ethnic basis alone. In fact, the only optimistic outcome for immigrants that can be derived from table 10 in terms of the immigration process is the case when you equip visible minority immigrant males with visible minority Canadian-born characteristics. Now you would lower the earnings of the immigrant visible minority group!

In sum, Table 11 indicates that visible minority immigrants suffer large earnings penalties circa 1991 in Canada with the penalties greater for men than women. In addition, Pendakur and Pendakur argue that these penalties are the least in Vancouver and the greatest in Montreal owing to different labor market structures.

\section{Summary}

What lessons does the Canadain labour market experience with immigrants yield for Europe? Does Canada's complicated structure of immigrant gateways with varying degrees of labor market tests have a significant impact on immigrant labor market outcomes? Does controlling the yearly immigrant intake in a countercyclical fashion imporve the short-term and life-time labor market chances for immigrants ? Does a universalistic acceptance policy in which Canada's immigrant intake world-wide replicates the world's population distribution work in the labor market? Is there a hidden rule of thumb to balance the entry 
classess across the refugee, family reunification and economic entry gates such that the economic outcomes benefit the resident population?

The answers to these questions in the Canadian context must be both in the short-run and longrun to yield appropriate policy lessons for the European context. The most dominant short-run admission rule which leads to immediate positive economic outcomes is the equal share rule. Under this rule Canada balances ist immigrant intake into $50 \%$ economic immigrants and 50\% all others including refugees and extended family members. This rule insures that any immigrant entry cohort imposes minimal short run labor displacement or wage compression on the Canadian-born segment of the labour market.

The logic of the $50 \%$ economic class admission rule is actually straight forward. One economically active entrant supports the other non-economic entrant with at least one strong positive experience in the labour market insured by an economic screening rule. For example, admission of an immigrant under the hihgly skilled or investor class produces enough jobs under this rule to offset any job displacement that occurs with the admission of refugees or family class members. In a dynmamic setting this rule also allows the forecasting of yearly intakes of immigrants. Thus, if Canada received on average 100,000 economically assessed immigrants over the past three years an extension of the fifty-fifty rule would imply 200,000 admissions the next year. In short, the recent past supply of economic immigrants allows a rule of thumb on Canada's ability to absorb future non-economically assessed immigrants. In addition, if the supply of economic immigrants to Canada shrinks as it has circa 1998-99, this implies a slowdown in the total number of immigrants in successive years.

The lesson for Europe to draw from Canada's universalistic acceptance policy is more circ umspect. Canada currently admits economic immigrants on primarily economic criteria and not country of origin characteristics. This places a small role for language (15 out of 105 points) or home labour market experience. This minimal emphasis on home country characteristics is incorrect. Knowledge of the dominant language in Canada is essential for economic integration and success. Minimal language skills must be learned by all economic entrants prior to their arrival to insure that their skills are to fully used. Language instruction after arrival while yielding high rates of return are expensive for the resident taxpayer and should be avoided. 
A parallell lesson to be drawn is that the admission of immigrants with substantial amounts of relevant human capital reinforces the positive labor market above outcomes and reduces the need to equip new immigrant arrivals with additional (physical) capital. What type of human capital is most relevant, specific or general ? Moreover, what complementary inputs are required to utilize this human capital in theCanadian labor market? A constellation of human capital attributes must be in place to insure that the human capital embodied in the immigrant is recognized and rewrded in the Canadian labor market. The most productive mixture of human capital attributes are a knowledge of English or French, youth (below age 40) and previous job experience and exposure to modern technologies. Thus, country of origin and place of acquisition of education is crucial. If the emobied human capital is irrelevant to the Canadian economy or if a language barrier prohibits recognition and assessment of skills then the labor market outcome is underemployment. Post-1990 highly skiled Canadian immigrants with professional degrees are underperforming previous highly skilled immigrants becanuse they lack language skills and adequate training (DeVoretz and Laryea, 1998). Thus, Chinese trained engineers are unemployed or drive taxis.

In sum, a mixture of general human capital; youth, language and higher education must be blended with specific skills and previous employment in a modern economy to insure postivie labor market outcomes and provide the economic stimulus to support a wide ranging immigration program with refugeses and family members. 


\section{REFERENCES}

Akbari, A. and D.J. DeVoretz (1992): “The Substitutability of Foreign-Born Labour in Canadian Production: Circa 1980,” Canadian Journal of Economics, 25, 604-614.

Altonji, J.G. and D. Card (1991): "The Effects of Immigration on the Labour Market Outcomes of Less-Skilled Natives," in J. Abowd and R. Freeman (eds.): Immigration, Trade and the Labour Market, Chicago: University of Chicago Press.

Beach, C.M. and C. Worswick (1993): "Is There a Double Negative Effect on the Earnings of Immigrant Women?" Canadian Public Policy, 19, 36-53.

Coulson, R.G. and D.J. DeVoretz (1993): “Human Capital Content of Canadian Immigration 1966-1987," Canadian Public Policy, 19, 357-366.

De New, J. P. and K.F. Zimmermann (1994): "Native Wage Impacts of Foreign-Born Labour: A Random Effects Panel Analysis," Journal of Population Economics, 7, 177-192.

DeVoretz, D.J. (1995): Diminishing Returns: The Economics of Canada's Immigration Policy: C.D. Howe Institute, Toronto and Laurier Institution, Vancouver.

DeVoretz, D.J. and S.A. Laryea (1998): Canadian Human Capital Transfers: The United States and beyond: C.D. Howe Institute, Toronto.

DeVoretz, D.J. and D. Maki (1980): “The Size and Distribution of Human Capital Transfers from LDC's to Canada 1966-1973," Economic Development and Cultural Change, 28, 779-800.

Friedberg, R.M. and J. Hunt (1995): “The Impact of Immigration on Host Country Wages, Employment and Growth," Journal of Economic Perspectives, 9, 23-44.

Globerman, S. (1995): "Immigration and Trade" in D.J. DeVoretz (ed.): Diminishing Returns: The Economics of Canada's Immigration Policy: C.D. Howe Institute, Toronto and Laurier Institution, Vancouver, 243-267.

Green, A.G. (1976): Immigration and the Post-War Canadian Economy, Toronto: Macmillan of Canada.

Grossman, J.B. (1982): “The Substitutability of Natives and Immigrants in Production,” Review of Economics and Statistics, 64, 596-603. 
Grubel, H.G. and A.D. Scott (1965): “The International Flow of Human Capital," American Economic Review, $56,277-280$.

Hawkins, F. (1991): Critical Years in Immigration: Canada and Australia Compared, Montreal: McGill/Queens University Press.

Hiebert, D. (1997): “The Colour of Work: Labour Market Segmentation in Montreal, Toronto and Vancouver, 1991," Working Paper No. 97-02, Vancouver Centre of Excellence: Research on Immigration and Integration in the Metropolis (RIIM).

Lalonde, R.J. and R.H. Topel (1991): “Labour Market Adjustment to Increased Immigration,” in J. Abowd and R. Freeman (eds.): Immigration, Trade and the Labour Market, Chicago: University of Chicago Press.

Laryea, S.A. (1997): “The Impact of Foreign-Born Labour on Wage Rates in Canada,” Unpublished Ph.D. Dissertation, Department of Economics, Simon Fraser University.

Marr, W. and M. Percy (1985): "Immigration Policy and Canadian Economic Growth,” in J. Whalley (ed.): Domestic Policy and the International Environment, Toronto: University of Toronto Press.

Michalowski, M. (1991): "Foreign-born Canadian Emigrants and their Characteristics", International Migration Review, 25, 28-59.

Newbold, K.B. (1996): "Internal Migration of the Foreign-Born in Canada," International Migration Review, 30, 728-747.

Pendakur, K. and R. Pendakur (1996): “The Colour of Money: Earnings Differentials Among Ethnic Groups in Canada," Working Paper No. 96-03, Vancouver Centre of Excellence: Research on Immigration and Integration in the Metropolis (RIIM).

Roy, A.S. (1997): "Job Displacement Effects of Canadian Immigrants by Country of Origin and Occupation," International Migration Review, 31, 150-161.

Seward, S.B. and M. Tremblay (1989): “Immigrants in the Canadian Labour Force: Their Role in Structural Change," IRPP Discussion Paper, 89.B.2, Ottawa.

Statistics Canada (1994): Canada's Changing Immigrant Population, Catalogue No. 96-311E. 